\title{
Macroamylasemia and Celiac Disease in a 6 -Year-Old Girl - Case Report
}

\author{
Virtut Velmishi ${ }^{1 *}$, Grisela Toci ${ }^{1}$, Gentiana Cekodhima ${ }^{2}$, Ermira Dervishi $^{1}$ and Paskal Cullufe ${ }^{1}$ \\ ${ }^{1}$ Department of Pediatric, Mother Teresa Hospital, Albania \\ ${ }^{2}$ Service of Histopathology, Mother Teresa Hospital, Albania
}

Submission: February 27, 2020; Published: March 11, 2020

*Corresponding author: Virtut Velmishi, Service of Pediatric, Department of Pediatrics, Mother Teresa Hospital, Dibra Street Nr 372, Albania

Abstract

Macroamylasemia is a biochemical disorder, resulting from circulation of macroamylase complexes in which amylase is bound to other macromolecules like immunoglobulins and polysaccharides, which increases their molecular weight, reducing renal excretion of these macromolecules and makes patients have chronically elevated serum amylase levels. Several diseases in association with macroamylasemia have been described, including celiac disease, in which macroamylasemia disappeared once the patients followed a gluten-free diet. We reported a pediatric case of macroamylasemia as a manifestation of celiac disease.

Keywords: Macroamylasemia; Immunoglobulins; Polysaccharides; Celiac disease; Gluten-free diet; Ulcerative colitis; Systemic lupus erythematosus; Abdominal ultrasound; IgA deficiency

\section{Introduction}

Macroamylasemia is defined as a biochemical disorder characterized by circulating complexes of amylase with macromolecules like immunoglobulins and polysaccharides, forming complexes known as macroamylase [1]. In association with macroamylasemia have been described several diseases, including IgA deficiency, celiac disease, lymphoma, HIV, carcinoma, ulcerative colitis, systemic lupus erythematosus, rheumatoid arthritis and liver disease [2-13]. Celiac disease (CD) is an immunemediated disorder resulting from a permanent intolerance to ingested gluten that results in inflammatory damage to the small intestinal mucosa. Macroamylasemia may resolve in patients with celiac disease following a gluten-free diet $[5,14]$. We describe a pediatric case of macroamylasemia associated with celiac disease.

\section{Case Report}

A 6-year-old girl was admitted to hospital with a 6-month history of abdominal pain, loss of appetite, weight loss, abdominal distension after eating. The abdominal pain was cramp-like pain localized in periumbilical area. According to her parents the abdominal pain is more frequent in the evening and in the last six months curve weight was decreasing: in May 2019 weight was 23 $\mathrm{kg}$, in November 2019 -3 kg. The parents denied having noticed vomiting and diarrhea. She was the second child of an Albanian couple. Pregnancy and delivery were normal. It was caesarean delivery. Birth weight was 3700 g. Nourished with breast milk. She was vaccinated according to Albanian schedule. There was no significant history of inherited or infectious disease in any of the family members. She was hospitalized before for upper respiratory tract infections. According to her parents in September 2019 she was consulted with the paediatric surgeon where resulted with no surgical problems and in a microscopic evaluation of stools for the presence of parasites was detected Giardia lamblia, and she was treated with oral metronidazole. Physical examination at admission noticed a relatively good general condition. Weight was $20 \mathrm{~kg}(-0.73 \mathrm{z})$ height was $120 \mathrm{~cm}(0.02 \mathrm{z})$ and body mass index 13.9 $\mathrm{kg} / \mathrm{m} 2(-1.19 \mathrm{z})$. Her axillary temperature was $36.8^{\circ} \mathrm{C}$, respiratory rate 22, heart rate 92 beats per minute. Breath sound was clear. Abdomen was soft, mild abdominal distension, no enlarged liver or spleen. Laboratory findings revealed: normal cell blood count; ERS=32 mm/h; CRP=2.29 mg/L. In biochemical examinations were noticed: serum amylase $165 \mathrm{U} / \mathrm{L}$; lipase $41 \mathrm{U} / \mathrm{L}$ and the rest of other examinations including the level of IgA was normal. Repeated amylase level in the serum confirmed the elevated value $178 \mathrm{U} / \mathrm{L}$. Serology for celiac disease (Anti-transglutaminase antibodies $\mathrm{Ig} \mathrm{A})$ resulted positive $78 \mathrm{U} / \mathrm{mL}(>15 \mathrm{U} / \mathrm{mL})$.

Abdominal ultrasound showed no abnormal findings. The patient underwent esophagogastroduodenoscopy where 4 duodenal biopsies were performed (Figure 1). At the same time we performed IgA anti EMA which resulted positive and HLA DQ2 DQ8 confirmed the diagnostic of celiac disease. Histological evaluation showed a villous atrophy compatible with March $3 \mathrm{~b}$ of celiac disease (Figure 2). The patient started a gluten-free diet. We have followed this girl three months later. She was playful and she has gained more than $1 \mathrm{~kg}$. We checked the level of amylase in blood which was in normal range. 


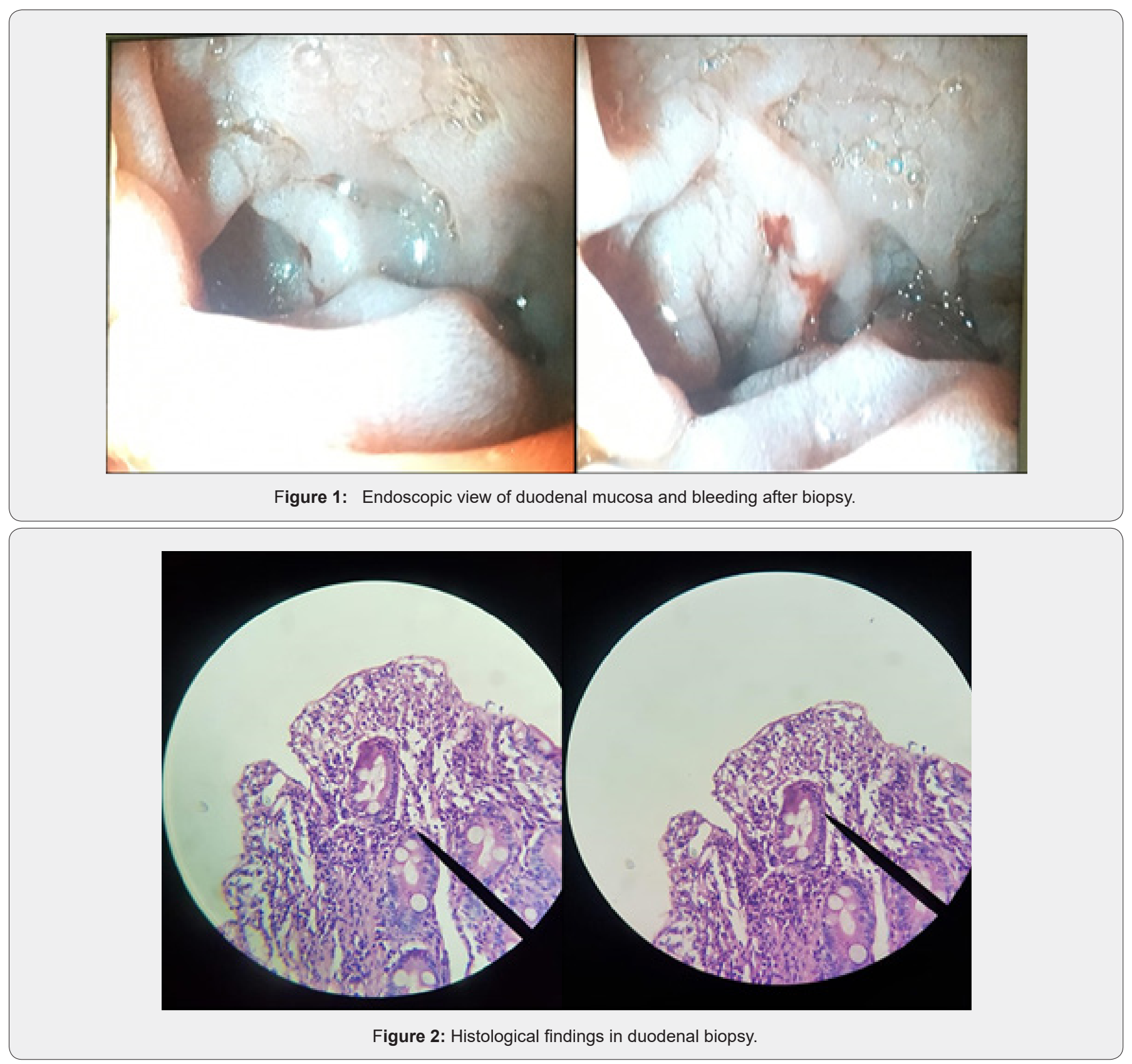

\section{Discussion}

We described a paediatric case where celiac disease is the cause of persistent hyperamylasemia. Celiac disease (CD) is a permanent intolerance to ingested gluten that results in immunologically mediated inflammatory damage of the small intestinal mucosa [15]. The "gold standart" to confirm Celiac Disease is considered histologic demonstration of the characteristic lesion in the small intestine, positive serology or genetic test and clinical response to the introduction of a gluten-free diet [16]. Macroamylasemia is a benign condition, results due to circulating macroamylase complexes, which cannot be filtered by the renal glomeruli [17]. The diagnosis of macroamylasemia in patients with isolated elevated amylase can be established by determining the molecular weight of the serum amylase, by immunologic assays, or the amylase-to creatinine clearance ratio (ACCR) [18]. In patients with macroamylasemia, the ACCR is reduced because of poor filtration of the large macroamylase complexes. In the absence of renal failure, a low ACCR is diagnostic of macroamylasemia [18].

The ratio is measured by the following formula:

ACCR $=$ Amylase(urine) $x$ Creatinine(serum) $\quad x \quad 100 /$ Amylase(serum) x Creatinine(urine)

A ratio less than 1 percent on a 24-hour collection supports the diagnosis of macroamylasemia indicating a poor clearance of amylase by the kidney (normal 3 to 4 percent) [19]. Due to 
diagnostic limitations of use of amylase electrophoresis, we use ACCR to confirm the diagnosis of Macroamylasemia. In our study we exlude acute pancreatitis, we have a normal renal function and a normal serum lipase, and a ratio ACCR less than 1 percent confirmed diagnosis. Macroamylasemia associated with Celiac Disease has been described in adult patients [20,21]. Bareara G et al, [22] hypothesize that some patients with MA are associated with silent $\mathrm{CD}$ and they suggest screening for $\mathrm{CD}$ in children with MA. Similarly, to our study, celiac disease was the cause of persistent hyperamylasemia in study of Kopelman et al. [23]. A few cases report correlation between MA and Celiac Disease in childhood and MA decreased or resolved in patients with celiac disease following a gluten-free diet [22,24-26].

\section{Conclusion}

We observed association between celiac disease and macroamylasemia in a pediatric case. In the presence of Macroamylasemia or elevated serum amylase without signs of pancreatitis the doctor should consider possibility of Celiac Disease. A strict gluten free diet is the cornerstone in treatment of Celiac disease but can lead in normal serum amylase in patients where celiac disease is associated with macroamylasemia.

\section{References}

1. Berk JE, Kizu H, Wilding P, Searcy RL (1967) Macroamylasemia: a newly recognized cause for elevated serum amylase activity. $N$ Engl J Med 277(18): 941-946.

2. Sachdeva CK, Bank S, Greenberg R, Blumstein M, Weissman S (1995) Fluctuations in serum amylase in patients with macroamylasemia. Am J Gastroenterol 90(5): 800-803.

3. Deprettere AJ, Eykens A, Van Hoof V (2001) Disappearance of macroamylasemia in a celiac patient after treatment with a gluten-free diet. J Pediatr Gastroenterol Nutr 33(3): 346-348.

4. Barera G, Bazzigaluppi E, Viscardi M, Renzetti F, Bianchi C, et al. (2001) Macroamylasemia attributable to gluten-related amylase autoantibodies: a case report. Pediatrics 107(6): E93.

5. Rabsztyn A, Green PH, Berti I, Fasano A, Perman JA, et al. (2001) Macroamylasemia in patients with celiac disease. Am J Gastroenterol 96(4): 1096-1100.

6. Eleccion CB, Hathaway AA (1998) Macroamylasemia in HIV infection. Tex Med 94(12): 77-79.

7. Bonetti G, Serricchio G, Giudici A, Bettonagli M, Vadacca GB, et al (1997) Hyperamylasemia due to macroamylasemia in adult gluten enteropathy. Scand J Clin Lab Invest 57(3): 271-273.

8. Yoshida K, Minegishi Y, Okawa H, Yata J, Tokoi S, et al. (1997) EpsteinBarr virus-associated malignant lymphoma with macroamylasemia and monoclonal gammopathy in a patient with Wiskott-Aldrich syndrome. Pediatr Hematol Oncol 14(1): 85-89.

9. Cutolo M, Sulli A, Barone A, Picciotto A, Mangraviti S, et al. (1995) Macroamylasemia: a possible cause of unexplained hyperamylasemia in rheumatoid arthritis. Br J Rheumatol 34(3): 290-292.

10. Fujimura Y, Nishishita C, Uchida J, Iida M (1995) Macroamylasemia associated with ulcerative colitis. J Mol Med (Berl) 73(2): 95-97.

11. Gallucci F, Madrid E, Esposito P, Uomo G (2007) Association of macroamylasemia and type I macro-creatine kinasemia. A case report. JOP 8(5): 605-608.

12. Torrent Vernetta A, Segarra Cantón O, Soler Palacín P, Segura Cardona RM, Infante Pina D (2008) Macroamylasaemia in paediatrics. An Pediatr (Barc) 69(5): 439-441.

13. Turkcapar N, Idilman R, Ensari A, Soylu K, Oz Ozyüncü Nden A (2006) Macro-amylasemia in a patient with selective IgA deficiency and antiphospholipid antibodies. Turk J Gastroenterol 17 (2): 140-143.

14. Van Gossum A, Cremer M (1989) Macroamylasemia disappearance after gluten withdrawal. Dig Dis Sci 34(6): 964-966.

15. Bransky D, Troncone R. (1998) Celiac disease: a reappraisal. J Pediatr 133(2): 181-187.

16. (1990) The Working Group of the European Society for Paediatric Gastroenterology and Nutrition. Revised criteria for diagnosis of coeliac disease. Arch Dis Child 65(8): 909-911.

17. Levine RI, Gleuser FL, Berk JE (1975) Enhancement of the amylasecreatinine clearance ratio in disorders other than acute pancreatitis. N Engl J Med 292(7): 329-332.

18. Levitt MD. (1979) Clinical use of amylase clearance and isoamylase measurements. Mayo Clin Proc 54(7): 428-431.

19. Dreiling DA, Leichtling JJ, Janowitz HD (1974) The amylase-creatinine clearance ratio. Diagnostic parameter or physiologic phenomenon? Am J Gastroenterol 61(4): 290-296.

20. Larvol L, Chagnon JP, Cerf M (1991) Celiac disease and macroamylasaemia. Am J Gastroenterol 86: 788.

21. Bonetti G, Serricchio G, Giudici A, Bettonagli M, Vadacca GB, et al. (1997) Hyperamylasemia due to macroamylasemia in adult gluten enteropathy. Scand J Clin Lab Invest 57(3): 271-273.

22. Barera G, Bazzigaluppi E, Viscardi M, Renzetti F, Bianchi C, et al. (2001) Macroamylasemia Attributable to Gluten-Related Amylase Autoantibodies: A Case Report. Pediatrics 107(6): E93.

23. Depsames R, Fireman Z, Niv E, Kopelman Y (2008) Macroamylasemia as the First Manifestation of Celiac Disease, Case Rep Gastroenterol 2(2): 196-198.

24. D’Avanzo M, Cobbaert C, Tolone C, Toraldo R, Canino G, et al. (1992) Macroamylasemia in a 5-year-old girl. J Pediatr Gastroenterol Nutr 14(1): 104-106.

25. Van Gossum A, Cremer M (1989) Macroamylasaemia disappearance after gluten withdrawal. Digest Dis Sci 34: 964-966. 
This work is licensed under Creative Commons Attribution 4.0 License

DOI:10.19080/ARGH.2020.15.555898

\section{Your next submission with JuniperPublishers will reach you the below assets}

- Quality Editorial service

- Swift Peer Review

- Reprints availability

- E-prints Service

- Manuscript Podcast for convenient understanding

- Global attainment for your research

- Manuscript accessibility in different formats

( Pdf, E-pub, Full Text, audio)

- Unceasing customer service

Track the below URL for one-step submission https://juniperpublishers.com/online-submission.php 